\title{
A RETROSPECTIVE STUDY ON PREVALANCE OF ANEMIA IN PREGNANCY IN A TERITIARY CARE HOSPITAL
}

\author{
SYEDA ZAINEB KUBRA HUSSAINI ${ }^{1 *}$, BUSHRA SHEREEN ${ }^{2}$, SIRISHA D ${ }^{1}$, MADHAVI E ${ }^{1}$, HARI PRIYA E ${ }^{1}$, HIMABINDU G ${ }^{1}$
}

${ }^{1}$ Department of Pharmacy Practice, Malla Reddy Pharmacy College, Hyderabad, Telangana, India. ${ }^{2}$ Department of $0 b s t e t r i c s$ and Gynecology, Malla Reddy Narayana Multispeciality Hospital, Hyderabad, India. Email: kubra687@gmail.com

Received: 25 May 2021, Revised and Accepted: 28 July 2021

\section{ABSTRACT}

Objective: To study about prevalence in anemia among the antenatal women, its clinical features, and access the severity and its treatment response.

Methods: A hospital-based retrospective study on the prevalence of anemia among the antenatal women in tertiary care hospital for 6 months duration in gynecology and obstetrics department. In evaluating pregnant women with anemia, it is essential to do a complete history and physical examination, as well as complete blood count with indices and a blood smear examination. Based on these findings, other test such as ferritin and serum or red cell folate may be ordered. Because of normal physiologic changes in pregnancy that effect the hematocrit, indices, and some other parameters, diagnosing true anemia, as well as the etiology of anemia, is challenging.

Results and Discussion: In this retrospective study, the prevalence of Anemia in pregnancy in a tertiary care hospital was evaluated and determined in fifty patients. The most common age group was between 21 and 25 years i.e., ( 21 patients) $42 \%$. Among 50 patients, majority of them, i.e., 35 patients (70\%) were treated with Injection. Iron Sucrose (200 mg). In this study, increase in prevalence were seen majorly in the third trimester, i.e., 25 patients (50\%) of which 22 patients $(88 \%)$ were with moderate anemia with 7.9 gm/dl average hemoglobin (Hb) percentage and 3 patients (12\%) were with mild anemia with $9.3 \mathrm{gm} / \mathrm{dl}$ average $\mathrm{Hb}$ percentage.

Conclusion: The plan of management for anemia complicating pregnancy depends on the type of anemia. Oral iron therapy is the route of choice in women with mild to moderate anemia and for severe anemia in pregnant women < 30 weeks of gestation. The rise of $\mathrm{Hb}$ with parenteral iron therapy is almost the same (avg: $1 \mathrm{gm} / \mathrm{dl} /$ week) as that of oral iron therapy.

Keywords: Anemia, Hemoglobin, Gravidity, Period of gestation.

(C) 2021 The Authors. Published by Innovare Academic Sciences Pvt Ltd. This is an open access article under the CC BY license (http://creativecommons.org/ licenses/by/4.0/) DOI: http://dx.doi.org/10.22159/ajpcr.2021v14i9.42327. Journal homepage: https://innovareacademics.in/journals/index.php/ajpcr

\section{INTRODUCTION}

The World Health Organization (WHO) defines anemia hemoglobin (Hb) $<11 \mathrm{gm} / \mathrm{dl}$ in the first trimester and third trimester and $<10.5 \mathrm{gm} / \mathrm{dl}$ in the second trimester. Anemia is further classified into mild, moderate, and severe by ICMR depending upon the level of $\mathrm{Hb}$.

- Mild $\mathrm{Hb} \%$ 10-10.9 gm\%

- Moderate $\mathrm{Hb} \%$ 7-10 gm\%

- Severe $\mathrm{Hb} \%$ 4-7gm\%

- Very severe: $<4$ gm $\mathrm{Hb} \%$. Anemia has multifactorial etiology [1].

As estimated by the WHO, the prevalence of anemia is $14 \%$ in developed countries, 51\% in developing countries, and 65-75\% in India [2,3].

In India, according to the recent National Family Health Survey-4 (NFHS-4) the prevalence of anemia is estimated to be $50.3 \%$. There has been a reduction in the prevalence of anemia from 58.3 (NFHS-3) to $50.3 \%$ (NFHS-4), there is not much difference in the prevalence of anemia reported in NFHS-2 (49.7\%) and NFHS-4 (50.3\%) [4]. India contributes to about $80 \%$ of maternal deaths in South Asia as estimated by WHO [3]

It is also associated with increased risk of miscarriage [5], prematurity, stillbirth, low birth weight, and consequently perinatal mortality [6]. Majority of iron transfer to the fetus occurs during the second and third trimester. The average daily requirement of iron has been calculated as $0.8 \mathrm{mg} / \mathrm{d}$ in the first trimester and increases to $7.5 \mathrm{mg} /$ day in the third trimester. The average daily absorption from a Western diet is 1-5 mg/day and average daily absorption from Indian diet varies from $0.8 \mathrm{mg} /$ day to $4.5 \mathrm{mg} /$ day depending on the type of staple used [7].
Dependent on the type of preparation only 1-8\% of iron is absorbed from the available oral iron preparations. There are considerable controversies regarding the optimal frequency, dose, and type of oral iron preparation to be used. The absorption of oral iron increases with increasing doses of oral iron only up to $160 \mathrm{mg} /$ day [8].

Accordingly, recommended dose of elemental iron for treating IDA in pregnancy is between 100 and $200 \mathrm{mg}$ /day in the British guidelines and $120 \mathrm{mg} / \mathrm{d}$ in the WHO guidelines [9]. In general, Ferric salts (III) have a superior gastrointestinal (GI) tolerability than Ferrous (II) salts at the cost of reduced iron absorption [10].

We recommend that parenteral iron should always be administered once ID is confirmed using serum ferritin or other specific investigations, after an informed consent at a center where resuscitation facilities are available. Vitals should be checked periodically during and at the end of infusion by a physician, nurse, or trained mid wife. A test dose is required only for LMW Iron dextran while other parenteral iron preparations do not require test dosing. Patient should be explained about the transient side effects of IV iron supplementation include nausea, vomiting, pruritus, headache, and flushing; myalgia, arthralgia, and back and chest pain that usually resolve within $48 \mathrm{~h}$ of infusion [11].

Ganzoni's equation is the standard formula used for calculating the dose of parenteral iron in pregnancy is [12]:

Required iron dose (mg)

$=(2.4 \times[$ target $\mathrm{Hb}-$ actual $\mathrm{Hb}]$

$\times$ pre - pregnancy weight $[\mathrm{kg}])$

$+1000 \mathrm{mg}$ for replenishment of stores 
Table 1: Distribution of patients based on Age groups

\begin{tabular}{lll}
\hline Age Groups & No. of Patients & Frequency (\%) \\
\hline$<20$ & 4 & 8 \\
$21-25$ & 21 & 42 \\
$26-30$ & 19 & 38 \\
$31-35$ & 2 & 4 \\
$>36$ & 4 & $8 \%$ \\
\hline
\end{tabular}

Table 2: Distribution of patients based on Clinical Features

\begin{tabular}{ll}
\hline Clinical features & No. of Patients \\
\hline Generalised weakness & 10 \\
Fatigue & 5 \\
Dizziness & 4 \\
Anxiety & 5 \\
Breathlessness & 6 \\
\hline
\end{tabular}

Table 3: Duration of Pregnancy Based on Gravidity

\begin{tabular}{lllllll}
\hline Duration of Pregnancy & $(0-1)$ & 2 & 3 & 4 & 5 & 6 \\
Gravidity No. of Cases & $18(36)$ & $21(42)$ & $5(10)$ & $2(4)$ & 0 & $1(2)$ \\
$\mathrm{n}(\%)$ & & & & & & \\
\hline
\end{tabular}

Table 4: Distribution of Patients based on severity of Anaemia

\begin{tabular}{lll}
\hline Severity Parameter & No. of Cases & Hb Percentage \\
\hline Mild & 8 & $(9-10.9 \mathrm{gm})$ \\
Moderate & 42 & $(7-8.9 \mathrm{gm})$ \\
Severe & 0 & $(4-7 \mathrm{gm})$ \\
\hline
\end{tabular}

Hb: Haemoglobin

Table 5: Classification of Anemia based on $\mathrm{Hb}$ assessment during three trimesters

\begin{tabular}{llll}
\hline $\begin{array}{l}\text { Trimesters } \\
\text { Hb }\end{array}$ & $\begin{array}{l}\text { No. of } \\
\text { patients }\end{array}$ & $\begin{array}{l}\text { Classification } \\
\text { of Anemia }\end{array}$ & $\begin{array}{l}\text { Levels of Average } \mathbf{H b} \\
\text { concentration }(\mathrm{gm} / \mathbf{d} \mathbf{l}) \\
\text { in percentage }\end{array}$ \\
\hline First & \multirow{2}{*}{09} & $\begin{array}{l}\text { Moderate } \\
\text { Mild }\end{array}$ & $\begin{array}{l}8.1 \\
\end{array}$ \\
& \multirow{2}{*}{16} & Normal & 0 \\
Second & Moderate & 7.8 \\
& & Mild & 9.3 \\
Third & \multirow{2}{*}{25} & Normal & 0 \\
& & Moderate & 7.9 \\
& & Mild & 9.3 \\
& & Normal & 0 \\
\hline
\end{tabular}

Hb: Haemoglobin

In practice, the dose can be titrated according to the available iron stores, history of ongoing blood loss, and $\mathrm{Hb}$ response.

Objectives

- To study about prevalence in anemia among the antenatal women

- To study its clinical features

- To access the severity and its treatment response.

\section{METHODS}

Inclusion criteria

- Antenatal women in $1^{\text {st }}, 2^{\text {nd }}$ and $3^{\text {rd }}$ trimesters

- Patients with age group of $<20$ to $>35$ years.

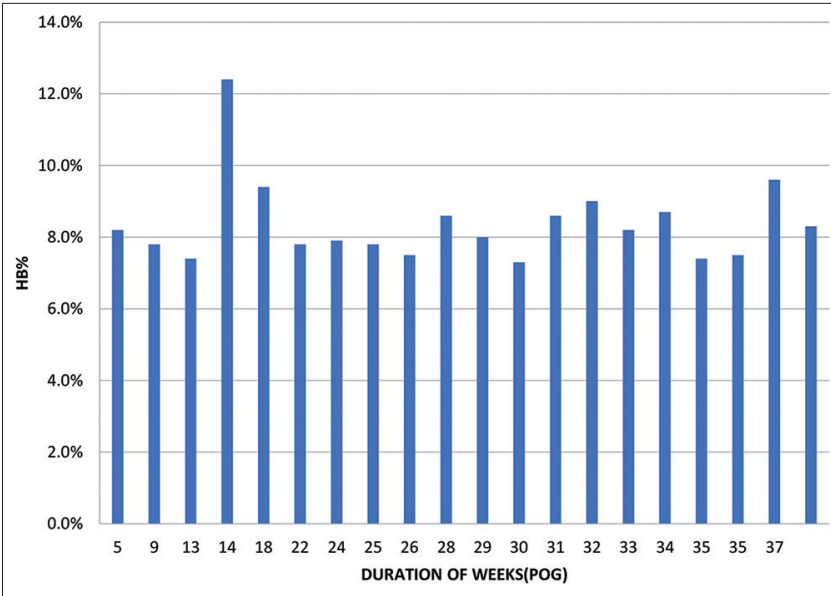

Fig. 1: Period of Gestation and Levels of Haemoglobin

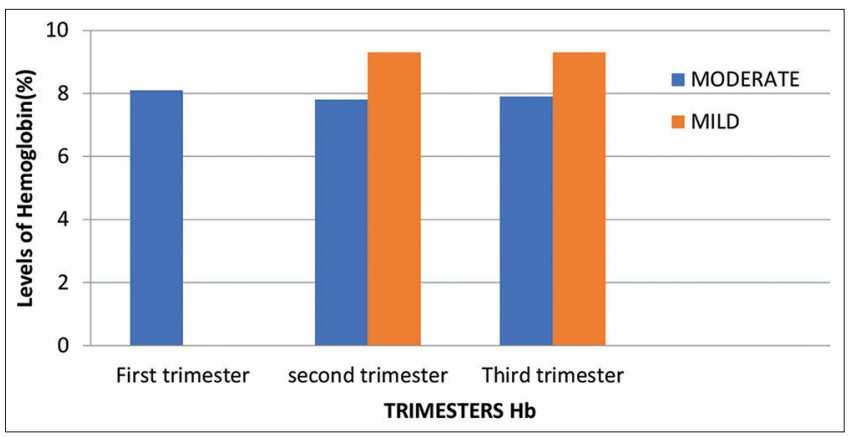

Fig. 2: Graphical representation on Hemoglobin Assessment during trimesters

Exclusion criteria

- Patients with $<18$ years of age

- Patients are not expected to cooperate and comply with the treatment

- Immune compromised patients.

\section{DISCUSSION}

In this retrospective study, the prevalence of Anemia in pregnancy in a tertiary care hospital was evaluated and determined in fifty patients. The most common age group was between 21 and 25 years i.e. (21 patients) $42 \%$. Major presenting complaints were generalized weakness, fatigue, dizziness, anxiety, and breathlessness in patients with Anemia. On evaluating the medical history two patients had blood transfusion, and one patient had history of hypothyroidism.

On enquiring for obstetric history as determined by Naegele's rule in the present population, Highest Gravidity was found in 21 patients (42\%) who were described as "gravida2" has had two pregnancies and two deliveries beyond 24 weeks or more of gestation. All patients were distributed and observed based on their gestational lengths and trimesters.

The route of administration of iron mainly depends on the severity of anemia and gestational age. The other factors being tolerance, absorption, and compliance. In general, oral Iron therapy is the preferred route. For treatment of iron deficiency anemia in pregnancy, the Government of India recommends $200 \mathrm{mg}$ elemental iron with $1 \mathrm{mg}$ folic acid per day until $\mathrm{Hb}$ levels raise to normal range and followed by $100 \mathrm{mg}$ per day as maintenance therapy (to be continued till 3 months after delivery to replenish iron stores). Oral iron therapy is given in the form of ferrous salts. There is no evidence of superiority of one 
preparation over the other. Preparations of low cost and lesser GI effects are to be prescribed for better compliance.

Out of 50 patients, first trimester (0-13 weeks) screening represented 9 patients with moderate anemia and there $\mathrm{Hb}$ values were $8.2 \mathrm{gm} / \mathrm{dl}$, $7.8 \mathrm{gm} / \mathrm{dl}, 8.6 \mathrm{gm} / \mathrm{dl}, 8 \mathrm{gm} / \mathrm{dl}, 8.7 \mathrm{gm} / \mathrm{dl}, 8.6 \mathrm{gm} / \mathrm{dl}, 7.8 \mathrm{gm} / \mathrm{dl}, 8.2 \mathrm{gm} / \mathrm{dl}$, $7.5 \mathrm{gm} / \mathrm{dl}$, respectively. Second trimester (14-26 weeks) represented 16 patients among which 11 patients were with moderate anemia and 5 patients were with mild anemia, there $\mathrm{Hb}$ values were found to be $7.8 \mathrm{gm} / \mathrm{dl}, 7.8 \mathrm{gm} / \mathrm{dl}, 7.5 \mathrm{gm} / \mathrm{dl}, 9.4 \mathrm{gm} / \mathrm{dl}, 7.4 \mathrm{gm} / \mathrm{dl}, 7.9 \mathrm{gm} / \mathrm{dl}$, $12.4 \mathrm{gm} / \mathrm{dl}, 9.6 \mathrm{gm} / \mathrm{dl}, 8.7 \mathrm{gm} / \mathrm{dl}, 8 \mathrm{gm} / \mathrm{dl}, 9.4 \mathrm{gm} / \mathrm{dl}, 9 \mathrm{gm} / \mathrm{dl}, 8.2 \mathrm{gm} / \mathrm{dl}$, $8.3 \mathrm{gm} / \mathrm{dl}, 7.4 \mathrm{gm} / \mathrm{dl}$, and $7.3 \mathrm{gm} / \mathrm{dl}$, respectively. Third trimester (2740 weeks) represented, majority of patients, i.e., 25 patients among which 22 patients were diagnosed with moderate anemia and 3 patients with mild anemia there $\mathrm{Hb}$ values were $8.6 \mathrm{gm} / \mathrm{dl}, 8 \mathrm{gm} / \mathrm{dl}, 8.7 \mathrm{gm} /$ dl, $8.6 \mathrm{gm} / \mathrm{dl}, 8.2 \mathrm{gm} / \mathrm{dl}, 7.5 \mathrm{gm} / \mathrm{dl}, 9 \mathrm{gm} / \mathrm{dl}, 7.4 \mathrm{gm} / \mathrm{dl}, 7.3 \mathrm{gm} / \mathrm{dl}$, $8.3 \mathrm{gm} / \mathrm{dl}, 9.6 \mathrm{gm} / \mathrm{dl}, 7.8 \mathrm{gm} / \mathrm{dl}, 8.2 \mathrm{gm} / \mathrm{dl}, 7.8 \mathrm{gm} / \mathrm{dl}, 7.8 \mathrm{gm} / \mathrm{dl}$, $7.5 \mathrm{gm} / \mathrm{dl}, 9.4 \mathrm{gm} / \mathrm{dl}, 7.4 \mathrm{gm} / \mathrm{dl}, 7.9 \mathrm{gm} / \mathrm{dl}, 8.4 \mathrm{gm} / \mathrm{dl}, 8.6 \mathrm{gm} / \mathrm{dl}, 7.8 \mathrm{gm} /$ dl, $7.5 \mathrm{gm} / \mathrm{dl}, 7.3 \mathrm{gm} / \mathrm{dl}$, and $7.9 \mathrm{gm} / \mathrm{dl}$, respectively.

The results augment the increase in prevalence was seen majorly in third trimester, i.e. 25 patients $(50 \%)$ of which 22 patients $(88 \%)$ were with moderate anemia with $7.9 \mathrm{gm} / \mathrm{dl}$ average $\mathrm{Hb}$ percentage and 3 patients $(12 \%)$ were with mild anemia with $9.3 \mathrm{gm} / \mathrm{dl}$ average $\mathrm{Hb}$ percentage.

\section{CONCLUSION}

Only $10 \%$ of ingested iron is usually absorbed. So at least ingestion of 40-60 mg of iron is required during pregnancy to achieve 4-6 mg of absorption. A balanced diet contains only 15-20 mg of elemental iron (i.e., $1.5-2 \%$ is only absorbed). Thus during pregnancy additional iron supplementation is mandatory. The WHO recommends universal iron supplementation for pregnant women with $60 \mathrm{mg}$ elemental iron and $250 \mathrm{mcg}$ folic acid daily for 6 months (i.e. after first trimester).

Government of India recommends $100 \mathrm{mg}$ elemental iron and $500 \mathrm{mcg}$ folic acid daily during the second half of pregnancy for a period of 100 days (starting from 14 to 16 weeks of gestation) and the same dose should be continued for 100 days in the postpartum period. The plan of management for anemia complicating pregnancy depends on the type of anemia. Oral iron therapy is the route of choice in women with mild to moderate anemia and for severe anemia in pregnant women $<30$ weeks of gestation.

The rise of $\mathrm{Hb}$ with parenteral iron therapy is almost same (avg: $1 \mathrm{gm} / \mathrm{dl} /$ week) as that of oral iron therapy. Intramuscular iron injection is usually given $100 \mathrm{mg}$ /day till total dose (or) Iron sucrose is usually given as a slow intravenous infusion of $200 \mathrm{mg}$ on alternate days till total estimated dose is covered. Among all the preparations, Iron sucrose and Iron carboxy maltose are the best and safe. Ironsucrose injections are even cost-effective and are the most commonly used preparation.

\section{AUTHORS CONTRIBUTION}

$2^{\text {nd }}$ Author were involved in planning and supervised the work. All authors provided critical feedback and helped shape the research, analysis and manuscript.

This publication (or project) was supported and carried out under JNTUH Affiliated Malla Reddy Pharmacy College.

\section{CONFLICTS OF INTEREST}

Nil.

\section{REFERENCES}

1. Vanderjagt DJ, Brock HS, Melah GS, El-Nafaty AU, Crossey MJ, Glew RH. Nutritional factors associated with anaemia in pregnant women in Northern Nigeria.J Health Popul Nutr 2007;25:75-8.

2. DeMayor EM, Tegman A. Prevalence of anaemia in the world. World Health Stat Q 1998;38:302-16.

3. Kalaivani K. Prevalence and consequences of anaemia in pregnancy. Indian J Med Res 2009;130:627-33.

4. NFHS-4, 2015-16; 2016. Available from: http://www.rchiips.org/nfhs/ pdf/nfhs4/india.pdf. [Last accessed on $2020 \mathrm{Jul} 12$ ].

5. Camargo RM, Pereira RA, Yokoo EM, Schirmer J. Factors associated with iron deficiency in pregnant women seen at a public prenatal care service. Rev Nutr 2013;26:455-64.

6. Brabin B, Sapau J, Galme K, Paino J. Consequences of maternal anaemia on outcome of pregnancy in a malaria endemic area in Papua New Guinea. Ann Trop Med Parasitol 1990;84:11-24.

7. Rammohan A, Awofeso N, Robitaille MC. Addressing female irondeficiency anaemia in India: Is vegetarianism the major obstacle? ISRN Public Health 2012;2012:765476.

8. Achebe MM, Gafter-Gvili A. How I treat anemia in pregnancy: Iron, cobalamin, and folate. Blood 2017;129:940-9.

9. World Health Organization. WHO Recommendations on Antenatal Care for a Positive Pregnancy Experience. Geneva, Switzerland: World Health Organization; 2016.

10. Ortiz R, Toblli JE, Romero JD, Monterrosa B, Frer C, Macagno E, et al. Efficacy and safety of oral iron (III) polymaltose complex versus ferrous sulfate in pregnant women with iron-deficiency anemia: A multicenter, randomized, controlled study. J Matern Fetal Neonatal Med 2011;24:1347-52.

11. Camaschella C. Iron deficiency: New insights into diagnosis and treatment. Hematology Am Soc Hematol Educ Program 2015;2015:8-13.

12. Koch TA, Myers J, Goodnough LT. Intravenous iron therapy in patients with iron deficiency anemia: Dosing considerations. Anemia 2015;2015:763576 